\title{
Isolation of Shiga toxin-producing Escherichia coli harboring variant Shiga toxin genes from seafood
}

\author{
Sreepriya Prakasan, Parmanand Prabhakar, Manjusha Lekshmi, Binaya Bhusan Nayak and Sanath Kumar \\ Department of Post-Harvest Technology, Quality Control Laboratory, ICAR-Central Institute of Fisheries Education, \\ Versova, Mumbai, Maharashtra, India. \\ Corresponding author: Sanath Kumar, e-mail: sanathkumar@cife.edu.in \\ Co-authors: SP: sreepriya.phtpa501@cife.edu.in, PP: parmanand1986@yahoo.com, ML: manjusha@cife.edu.in, BBN: \\ nayakbb@cife.edu.in
}

Received: 12-12-2017, Accepted: 21-02-2018, Published online: 28-03-2017

doi: 10.14202/vetworld.2018.379-385 How to cite this article: Prakasan S, Prabhakar P, Lekshmi M, Nayak BB, Kumar S (2018) Isolation of Shiga toxin-producing Escherichia coli harboring variant Shiga toxin genes from seafood, Veterinary World, 11(3): 379-385.

\begin{abstract}
Background and Aim: Shiga toxin-producing Escherichia coli (STEC) are important pathogens of global significance. STEC are responsible for numerous food-borne outbreaks worldwide and their presence in food is a potential health hazard. The objective of the present study was to determine the incidence of STEC in fresh seafood in Mumbai, India, and to characterize STEC with respect to their virulence determinants.

Materials and Methods: A total of 368 E. coli were isolated from 39 fresh seafood samples (18 finfish and 21 shellfish) using culture-based methods. The isolates were screened by polymerase chain reaction (PCR) for the genes commonly associated with STEC. The variant Shiga toxin genes were confirmed by Southern blotting and hybridization followed by DNA sequencing.

Results: One or more Shiga toxins genes were detected in 61 isolates. Of 39 samples analyzed, 10 (25.64\%) samples harbored STEC. Other virulence genes, namely, eaeA (coding for an intimin) and hlyA (hemolysin A) were detected in 43 and 15 seafood isolates, respectively. The variant stx 1 genes from 6 isolates were sequenced, five of which were found to be stxld variants, while one sequence varied considerably from known stx 1 sequences. Southern hybridization and DNA sequence analysis suggested putative Shiga toxin variant genes (stx2) in at least 3 other isolates.
\end{abstract}

Conclusion: The results of this study showed the occurrence of STEC in seafood harboring one or more Shiga toxin genes. The detection of STEC by PCR may be hampered due to the presence of variant genes such as the stxld in STEC. This is the first report of stx $1 d$ gene in STEC isolated from Indian seafood.

Keywords: Escherichia coli, pathogen, seafood, Shiga toxin, Shiga toxin-producing Escherichia coli, virulence gene.

\section{Introduction}

Escherichia coli have historically been considered as an indicator of fecal contamination of water and food. More than 700 serotypes of E. coli have been identified and majority of these are non-pathogenic commensals of the human and animal gastrointestinal tract [1]. However, a small percentage of $E$. coli serotypes have acquired the ability to cause versatile infections ranging from wound infections to fatal meningitis in humans of all age groups [2]. The pathogenic $E$. coli represent a small group of highly specialized strains or serotypes which have specifically evolved to infect humans and animals [3].

E. coli causing intestinal infections belong to at least 5 groups of which the Shiga toxin-producing E. coli (STEC), also known as the enterohemorrhagic

Copyright: Prakasan, et al. Open Access. This article is distributed under the terms of the Creative Commons Attribution 4.0 International License (http://creativecommons.org/licenses/ by/4.0/), which permits unrestricted use, distribution, and reproduction in any medium, provided you give appropriate credit to the original author(s) and the source, provide a link to the Creative Commons license, and indicate if changes were made. The Creative Commons Public Domain Dedication waiver (http:// creativecommons.org/publicdomain/zero/1.0/) applies to the data made available in this article, unless otherwise stated.
E. coli (EHEC), are the most serious pathogens. In the United States alone, STEC infections result in 100,000 illnesses, 3000 hospitalizations and 90 deaths annually [4]. Since animals such as cattle, sheep, and goat are the main reservoirs of STEC, infections generally occur through consumption of meat and milk that are inadequately pasteurized. The primary virulence factor of STEC is the production of one or more Shiga toxins. Shiga toxins (Stx) are of two types; Stx1, which is more or less identical to the toxins produced by Shigella dysenteriae 1, and Stx2, which has about $60 \%$ similarity with Stx1 [5,6]. Production of one or more Shiga toxins is essential to cause disease, but the production of Stx2 is more correlated with the severity of the disease such as hemolytic uremic syndrome (HUS) and HC [7]. Stx1 is more conserved compared to Stx 2 with few variants such as Stx1c and Stx1d, while several sequence variants of Stx 2 Stx $2 a, S t x 2 b, S t x 2 c$, Stx2d, Stx2e, Stx2f, and Stx2g have been reported [8]. Among these, Stx2 subtypes Stx2a, Stx2c, and Stx2d are commonly associated with severe forms of STEC infections leading to HUS and hemorrhagic colitis (HC) $[9,10]$. In addition to the production of one more Shiga toxins, several accessory virulence factors are 
known to determine the pathogenicity of STEC in human infections. Some of the important virulence factors of STEC include the ability to form attachment and effacement lesions (A/E lesions) and production of an enterohemolysin (HlyA) [11]. Although the role of these virulence factors is not fully established, they have been frequently detected if not always, among STEC isolated from clinical cases of HUS and HC. Although roughly 400 serotypes of STEC produce Shiga toxins, all of them are not implicated in human infections. Serotype O157:H7 is the most common serotype involved in severe cases of infections leading to HUS and HC, and majority of the large-scale outbreaks of STEC infections have been associated with this serotype [12]. Several other serotypes, generally termed as non-O157 serotypes such as O26, O45, O91, O103, O111, O121, and O145, are also involved in severe human infections $[13,14]$.

Since food animals harbor STEC, foods of animal origin are naturally contaminated with STEC [15]. Fecal shedding of STEC and subsequent contamination of surrounding environments leads to spread of STEC to other foods. The occurrence of STEC in seafood is due to secondary contamination from water, handlers of seafood or cross-contamination from other foods [16-18]. STEC isolated from seafood in India, by far, are of non-O157 serotype $[16,18]$. The true pathogenic potentials of these isolates are not known. Since seafood is contaminated from terrestrial sources, it is expected that STEC isolates from seafood could be serologically and genetically very diverse. Further, aquatic environment is an ideal niche for complex genetic interactions involving exchange of genetic materials among closely related bacteria leading to the evolution of new pathogens.

In the present study, STEC were isolated from seafood and characterized for the commonly associated virulence genes. The presence of Shiga toxin genes was tested using different sets of primers, and the putative variant stx genes were sequenced. The sequence variants were compared to identify the occurrence of a new variant stx gene in seafood isolates of STEC.

\section{Materials and Methods \\ Ethical approval}

Since no animals were used in this study, ethical approval was not needed.

\section{Collection of samples and bacteriological analysis}

A total of 39 seafood samples (18 finfish and 21 shellfish) were collected during August 2014-April 2015 from landing centers and retail fish markets in the western Mumbai, India. The samples were placed in a sterile plastic bag and transported to the laboratory in chilled condition within $1 \mathrm{~h}$ of collection for bacteriological analysis. Tryptone phosphate broth (TP) and HiCrome EC broth (HiMedia, Mumbai) were used as selective enrichment broths [19]. $25 \mathrm{~g}$ of the sample was aseptically weighed and transferred to a stomacher bag (Seward Medical, London, UK), homogenized for $60 \mathrm{~s}$ in a stomacher (Seward Stomacher 80, Lab system, London, UK) and added to $225 \mathrm{~mL}$ of TP broth or HiCrome EC broth. The TP broth was incubated at $44.5^{\circ} \mathrm{C}$ for $24 \mathrm{~h}$, while HiCrome EC broth was incubated at $37^{\circ} \mathrm{C}$ for $24 \mathrm{~h}$. Following incubation, two loopful from the enrichment broths were streaked on two different selective agar plates Sorbitol MacConkey Cefixime Agar (SMAC) (HiMedia, Mumbai) supplemented with tellurite-cefixime and HiCrome O157:H7 agar (HiMedia, Mumbai) supplemented with potassium tellurite. The plates were incubated for $18-24 \mathrm{~h}$ at $37^{\circ} \mathrm{C}$. Typical E. coli colonies, 3-5 from each selective plate, were purified on Luria Bertani Agar plates and subjected to biochemical tests for the identification for $E$. coli which included oxidase test, indole production, methyl red-VogesProskauer, and citrate utilization tests [19].

\section{Extraction of genomic DNA}

Genomic DNA from E. coli isolates was extracted using cetyltrimethylammonium bromide (CTAB) method [20]. Briefly, a $5 \mathrm{~mL}$ of the culture was centrifuged, and the pellet was resuspended in $456 \mu \mathrm{L}$ of $1 \times \mathrm{TE}(1 \mathrm{mM}$ Tris, $\mathrm{pH} 8 ; 10 \mathrm{mM}$ EDTA) buffer, followed by the addition of $30 \mu \mathrm{L}$ of $10 \%$ SDS and $3 \mu \mathrm{L}$ of proteinase $\mathrm{K}(20 \mathrm{mg} / \mathrm{mL})$. The mixture was incubated for $1 \mathrm{~h}$ at $37^{\circ} \mathrm{C}$. Following this, $100 \mu \mathrm{L}$ of $5 \%$ CTAB and $80 \mu \mathrm{L}$ of $100 \mathrm{mM} \mathrm{NaCl}$ were incubated at $65^{\circ} \mathrm{C}$ for $15 \mathrm{~min}$. The mixture was extracted with an equal volume $(600 \mu \mathrm{L})$ of phenol, chloroform, and isoamyl alcohol (25:24:1) and centrifuged at $10,000 \mathrm{rpm}$ for $10 \mathrm{~min}$. The aqueous layer was extracted with an equal volume chloroform and isoamyl alcohol (24:1) and centrifuged at 10,000 rpm for $10 \mathrm{~min}$. DNA was precipitated using 0.6 volumes of isopropanol, washed with $70 \%$ ethanol, air dried and dissolved in $1 \times$ TE buffer. The concentration and the purity of DNA were measured using Nanodrop spectrophotometer (Thermo Scientific, USA).

\section{Polymerase chain reaction (PCR) for virulence genes of STEC}

The E. coli isolates were subjected to PCR for the detection of virulence genes commonly associated with STEC using previously described oligonucleotide primers and thermocycling conditions (Table-1) [21-27]. All PCRs were performed in a Prima-96 thermocycler (HiMedia, Mumbai). The amplicons were separated on a $1.6 \%$ agarose gel, stained with ethidium bromide (HiMedia, Mumbai) and photographed using a gel documentation system (Bio-Rad, USA). An EHEC strain EDL 933 was used as the positive control in all PCR reactions.

\section{Southern blotting and hybridization}

The non-specific stx2 amplicons obtained with 12 E. coli isolates were subjected to Southern hybridization to determine if they contained Shiga toxin gene sequences. A biotin-labeled probe was 
prepared using stx2 PCR product from the reference strain USFDA (serotype O157:H7) using Biotin DecaLabel DNA labeling kit (Thermo Scientific, USA). PCR products were separated on a $1.5 \%$ agarose gel and Southern blotted onto a positively charged nylon membrane (SensiBlot Plus, Thermo Scientific, USA) in an alkaline condition [28], and hybridized with the biotin-labeled probe at $42^{\circ} \mathrm{C}$ overnight [29]. Following this, the membrane was washed twice with $5 \times \mathrm{SSC}, 0.5 \%[\mathrm{~W} / \mathrm{V}] \mathrm{SDS}$ at $50^{\circ} \mathrm{C}$ for $5 \mathrm{~min}$ each, $0.1 \times \mathrm{SSC}, 1 \%[\mathrm{~W} / \mathrm{V}] \mathrm{SDS}$ at $42^{\circ} \mathrm{C}$ for $15 \mathrm{~min}$ each, and once with $2 \times \mathrm{SSC}$ for $5 \mathrm{~min}$ at room temperature. The membrane was incubated with a blocking solution for $1 \mathrm{~h}$ at $60^{\circ} \mathrm{C}$, followed by incubation with streptavidin-alkaline phosphatase (1:5000 diluted) for $10 \mathrm{~min}$ at room temperature. The color development was done by placing the membrane in BCIP-NBT $(330 \mu \mathrm{g} / \mathrm{mL}$ NBT and $167 \mu \mathrm{g} / \mathrm{mL}$ BCIP) solution in the dark with gentle shaking. The color reaction is terminated by rinsing the membrane in stop solution $(20 \mathrm{mM}$ Tris- $\mathrm{HCl}$ pH 7.5, 5 mM EDTA).

\section{Nucleotide sequence accession numbers}

The nucleotide sequences of $s t x 1$ genes derived in this study have been deposited in GenBank under accession numbers KR632986, KR632985, KR632984, KR632983, and KR632982.

\section{Results}

\section{Isolation of STEC from seafood samples}

Of 670 isolates screened from 39 samples finfish and shellfish, 368 (54.9\%) were confirmed as E. coli isolates by biochemical tests and PCR. A total of $10(25.64 \%)$ seafood samples were positive for STEC which comprised 3 fish and 7 shellfish samples (Table-2). E. coli were present in all the samples $(100 \%)$ analyzed in this study. When the numbers of isolates from different selective agars were compared, of 368 isolates from seafood samples, $258(70 \%)$ were from SMAC, and $110(30 \%)$ were from HiCrome agar suggesting that SMAC allowed better isolation of $E$. coli from seafood compared to the chromogenic agar. Further, of 368 E. coli isolates 208 (56.5\%) were from fish and $160(43.5 \%)$ were from shellfish.

\section{Genotyping of STEC isolates}

The common primers VTcom-F and VTcom-R [21] amplifying common regions of stx1 and stx 2 genes detected Shiga toxin genes in 61 isolates. Further, seven STEC isolates which included 4 isolates from clams (CEC-1, CEC-2, CEC-3, and CEC-4) and 3 from oysters (OYEC-5, OYEC-6, and OYEC-7) were among those which yielded specific amplicons with common primers (Table-1) [21-29], but not with specific stx 1 or stx 2 primers (Figure-1). These were further characterized by sequencing the

Table-1: PCR primers used in this study and their target genes.

\begin{tabular}{|c|c|c|c|c|}
\hline Primer & Target gene & Sequence $\left(5^{\prime}-3^{\prime}\right)$ & Product size (bp) & Reference \\
\hline stx1F-PA & $s t \times 1$ & ATAAATCGCCATTCGTTGACTAC & 180 & {$[23]$} \\
\hline stx1R-PA & & AGAACGCCCACTGAGATCATC & & \\
\hline stx $2 \mathrm{~F}$ & stx2 & GGCACTGTCTGAAACTGCTCC & 255 & \\
\hline stx2R & & TCGCCAGTTATCTGACATTCTG & & \\
\hline eaeAF & eaeA & GACCCGGCACAAGCATAAGC & 384 & \\
\hline eaeAR & & ССАССTGCAGCAACAAGAGG & & \\
\hline hlyAF & hlyA & GCATCATCAAGCGTACGTTCC & 534 & \\
\hline hlyAR & & AATGAGCCAAGCTGGTTAAGCT & & \\
\hline VT-comF & Common for stx 1 and stx 2 & GAGCGAAATAATTTATATGTG & 518 & {$[21]$} \\
\hline VT-comR & & TGATGATGGCAATTCAGTAT & & \\
\hline stx1F-FA & st $\times 1$ & CCATGACAACGGACAGCAGTT & 779 & {$[22]$} \\
\hline stx1R-FA & & CCTGTCAACTGAGCAGCACTITG & & \\
\hline st $x 2 F-F A$ & stx2 & GTGGCGAATACTGGCGAGACT & 890 & \\
\hline stx2R-FA & & ССССАTTCTITITCACCGTCG & & \\
\hline eaeAF -FA & eaeA & ACACTGGATGATCTCAGTGG & 614 & \\
\hline eaeAR-FA & & CTGAATCCСССТССАТTATG & & \\
\hline hlyAF-FA & hlyA & ACGATGTGGTTTATTCTGGA & 166 & \\
\hline hlyAR-FA & & CTTCACGTGACCATACATAT & & \\
\hline $\begin{array}{l}\text { st } \times 1 C-F \\
\text { st } \times 1 C-R\end{array}$ & st $x 1 c$ variant & $\begin{array}{l}\text { TITCACATGTTACCTTCCT } \\
\text { CATAGAAGGAAACTCATTAG }\end{array}$ & 498 & {$[26]$} \\
\hline MK1 & Common for stx 1 and stx 2 & TTTACGATAGACTTCTCGAC & 230 & [24] \\
\hline MK2 & & CACATATAAATTATTTCGCTC & & \\
\hline BGRIU & stx1-full & TCAACGAAAAATAACTTCGCTGAATCCC & 1178 & {$[25]$} \\
\hline BGRID & & CAGTTAATGTGGTTGCGAAGGAATTTACC & & \\
\hline BGR2U & stx2 -full & ATGAAGTGTATATTATTTAAATGGGTACTGTG & 1226 & \\
\hline BGR2D & & TCAGTCATTATTAAACTGCACTTCAG & & \\
\hline VT1AF & stx1-full & TCGTATGGTGCTCAAGGAGT & 966 & {$[27]$} \\
\hline VT1AR & & AGTTCTGCGCATCAGAATTG & 1309 & \\
\hline VT1BR2 & & AGAACCGGCAACAACTGACT & & \\
\hline
\end{tabular}

Thermocycling conditions: $94^{\circ} \mathrm{C}-1 \mathrm{~min}, 55^{\circ} \mathrm{C}-1 \mathrm{~min}, 72^{\circ} \mathrm{C}-1 \mathrm{~min}$ for $s t \times 1$, st $\times 2, h l y A$, eaeA, and st $\times 1$ full gene amplification (BGRIU/BGRID); $94^{\circ} \mathrm{C}-1 \mathrm{~min}, 51^{\circ} \mathrm{C}-1 \mathrm{~min}, 72^{\circ} \mathrm{C}-1 \mathrm{~min}$ for st $\times 1 \mathrm{C} ; 94^{\circ} \mathrm{C}-1 \mathrm{~min}, 55^{\circ} \mathrm{C}-1 \mathrm{~min}, 72^{\circ} \mathrm{C}-2 \mathrm{~min}$ for st $\times 2$-full gene amplification (BGR2U/BGR2D and VT1AF/VT1AR/VT1BR2), PCR=Polymerase chain reaction 
Table-2: Details of seafood sample analyzed and the isolation of STEC.

\begin{tabular}{|c|c|c|c|}
\hline Type of sample & Number of samples (n) & Number $(\%)$ of STEC positive samples & Number of STEC* isolated \\
\hline Fish & 18 & $3(16.6)$ & 25 \\
\hline Shellfish & 21 & $7(33.33)$ & 36 \\
\hline Total & 39 & $10(25.64)$ & 61 \\
\hline
\end{tabular}

*Positive for at least one stx gene, STEC=Shiga toxin-producing Escherichia coli

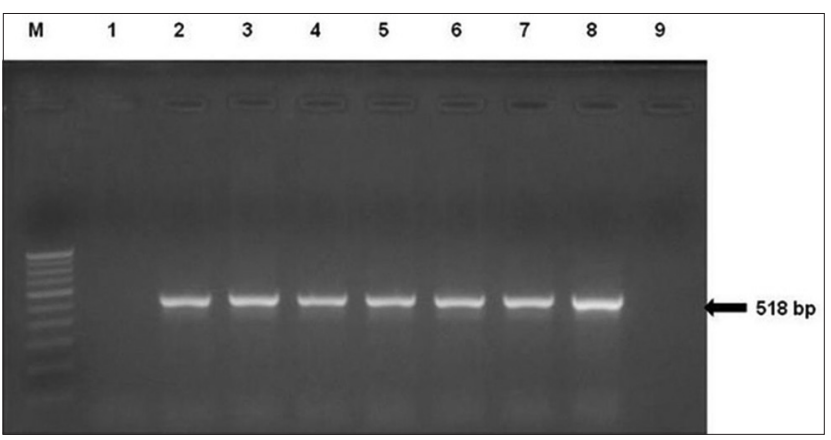

Figure-1: Amplification of stx gene using a common primer for both stx 1 and st 2 genes. Lane M: 100 bp DNA ladder, Lanes 2-7: Escherichia coli isolates from oysters and clams, Lane 8: Positive control (E. coli O157:H7), Lanes 1 and 9: Negative control.

full length stx gene amplified using primers BGRIU and BGRID (Table-1) [21-29]. Sequence analysis of $1.3 \mathrm{~kb}$ stx genes from 5 isolates revealed that these isolates are positive for stxl gene of stxld variant type. The seven stxl-positive isolates were further characterized for additional virulence genes by PCR and were found to be negative for stx 2 gene, $h l y A$, and eaeA genes. Further, the stx gene of isolate CEC-1 could not be amplified using stx common primers, as well as the stxl-specific primers [22], but could be amplified using another set of stxl-specific primers [23]. Similar discrepancies with stx amplifications could be seen with the isolate CEC-5, presumably due to sequence differences in primer binding sites. The full sequence of stx 1 gene in 5 isolates (CEC-2, CEC-3, CEC-4, OYEC-5, and OYEC-6) was obtained using different combination of primers stx1F-PA and BGRID (Table-1) [21-29].

A few E. coli isolates, 22 in number, which yielded weak amplicons with common stx primers [21], did not yield any amplification with either stx 1 - or st $x 2$-specific primers (data not shown). It was hypothesized that isolates could be harboring sequence variants of Shiga toxin genes which were not amplifiable by existing primers [16]. These isolates were screened for stx genes using a different pair of $s t x$ common primers, MK1 and MK2 (Table-1) [21-29]. Four isolates showed expected amplicons, while the remaining isolates yielded non-specific amplicons (data not shown). Further, 7 isolates (SST1, SST2, SST3, SST4, SST5, SST6, and SST7) from a sample of fish showed amplicons of different but uniform sizes with stx2-specific primers (Figure-2). The PCR products obtained with SST1-SST7 were sequenced and BLAST analysis revealed that these were indeed stx 2 gene amplification products. All 7 isolates were positive for hlyA and eaeA genes confirming their identity as STEC. In addition, an isolate of $E$. coli (SEHC3) consistently yielded faint amplification with stx2 primers stx2F-FA and stx2R-FA [22]. Since the sequencing of this faint amplicon was not possible, Southern hybridization was performed using biotin-labeled polynucleotide probe derived from the stx 2 PCR product of O157:H7 reference strain. The $s t x 2$ PCR product of SEHC3 reacted with the probe suggesting the presence of st 2 sequence (Figure-3).

\section{Discussion}

The presence of $E$. coli in seafood indicates fecal contamination from human-animal sources since $E$. coli are not normal inhabitants of the coastal-marine environments [30]. Since a proportion of E. coli can harbor genes that can contribute to their ability to cause a range of infections in humans and animals, the focus on $E$. coli in food has now been shifted from their role as indicators of fecal contamination to important agents of food-borne human infections. The contamination of coastal-marine environments from anthropogenic sources will lead to contamination of seafood harvested from such waters with human enteric pathogens. Routine monitoring of coastal environments and the seafood will help in identification of critical points of contamination of seafood and plan scientific interventions to prevent such contaminations. In this regard, the present study was aimed at screening fresh seafood for the presence of STEC. STEC was detected in 10 (25.64\%) seafood samples (Table-2). For the isolation of pathogenic E. coli, two enrichment broths (TP broth and HiCrome EC broth) and two selective agars (SMAC agar and HiCrome O157:H7 EC agar) were used. Both the selective agars contained antibiotics as selective agents. Pathogenic strains of $E$. coli occur in very small numbers in a background of large number of other related enterobacteria which may outgrow the pathogenic E. coli when less selective media are used. However, these two selective agars varied with respect to the number of $E$. coli isolated on them, with SMAC yielding 70\% and HiCrome O157:H7 agar yielding 30\% of all the isolates of $E$. coli obtained in this study.

Several studies in the past two decades have reported the prevalence of STEC in different types of foods including seafood in India. The first report on the isolation of STEC from India was from non-diarrheic animal sources [31]. STEC were isolated and characterized from animals, humans and food products, 


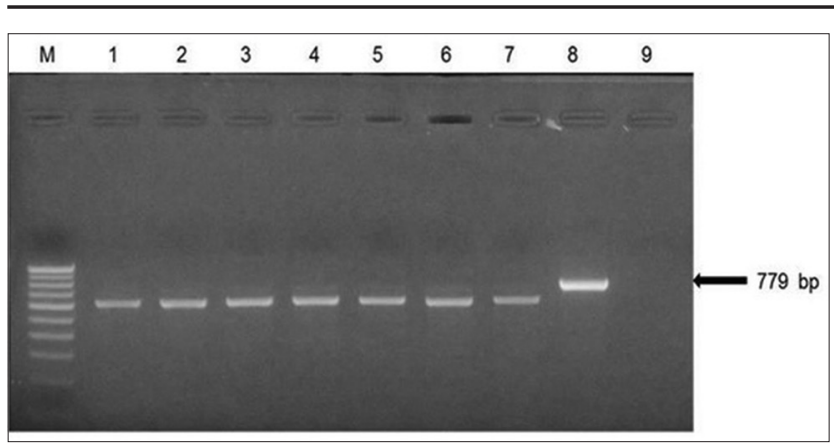

Figure-2: Polymerase chain reaction (PCR) amplification of stx2 genes in Escherichia coli isolates from fish using primers stx2F-FA and stx2R-FA. The isolates yielded smaller amplifications products compared to the expected product of $779 \mathrm{bp}$. The presence of stx 2 sequences in the amplicons was confirmed by sequencing of PCR products. Lane $\mathrm{M}$ : 100 bp DNA ladder, Lanes 1-7: E. coli isolates from Bregmaceros mcclellandi (spotted codlet), Lane 8: Positive control (E. coli O157:H7), lane 9, negative control.

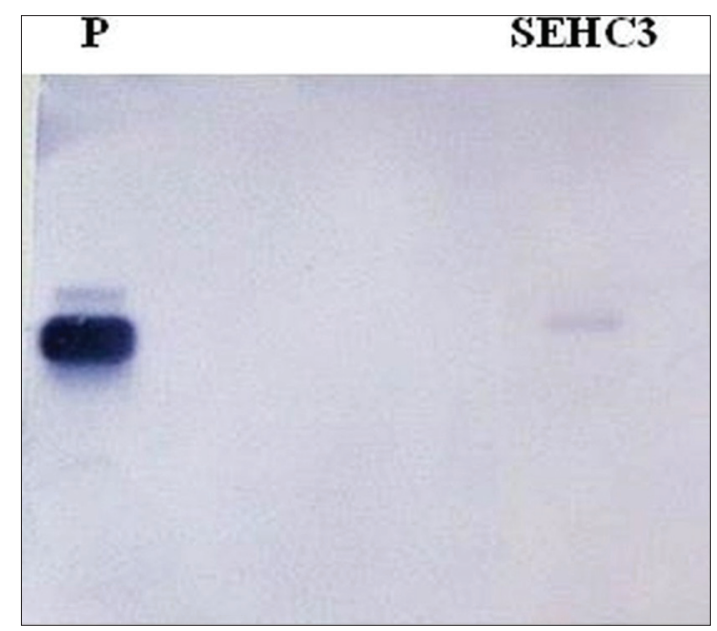

Figure-3: Escherichia coli SEHC3 isolated from the fish Scomberomorus commerson yielded faint amplicon with a stx2-specific polymerase chain reaction (PCR). The presence of stx 2 gene sequence in the amplicon was confirmed by Southern hybridization with a biotin-labeled probe. Lanes $\mathrm{P}$ : stx2 amplification product of reference strain $E$. coli 0157:H7, Lane SEHC3: stx2 PCR product of SEHC3.

as well as from diarrheic calves and lambs [32,33]. In an elaborate study [34], 876 samples which included 330 animals, 184 humans, and 362 food samples were screened, and 17 STEC strains were isolated. These isolates harbored different combinations of virulence genes such as $s t x 1$ and $s t x 2$ (44.5\% of strains), stx2 alone (44.5\%) and stx2 and hlyA (19\%) [33]. Studies on the prevalence and characterization of STEC in seafood in India are limited. The occurrence of STEC in seafood in India was first reported in 2001 [18]. In this study, STEC were isolated from $5 \%$ of clams and $3 \%$ of fresh fish samples [18]. Seafood isolates of STEC harbored different combinations of stx genes and were mostly of non-O157 serotypes [16]. A study from Cochin, India reported the isolation of $\mathrm{O} 157: \mathrm{H} 7$ from shrimp samples [35]. These studies strongly suggest the association of STEC with seafood, although the exact sources of these STEC have not been scientifically demonstrated.
In this study, different $\mathrm{PCR}$ primers and protocols were used detect Shiga toxin genes of STEC associated with seafood. 61 isolates of $E$. coli harbored one or more Shiga toxin genes. No single primer pair was able to detect stx genes in all isolates of this study. Sequencing and Southern hybridization were performed to detect stx gene sequences in cases of ambiguity. Nucleotide sequencing enabled detection of stx 2 gene sequences in 7 STEC isolates (SST1-SST7) from a fish sample (Figure-2). The presence of hlyA and eaeA genes in these isolates further confirmed their identity as STEC. However, amplification of fulllength stx2 gene from these isolates was not successful using primers shown in Table-1 [21-29]. Further, an isolate of E. coli (SEHC3) which consistently yielded faint amplification with stx2 primers stx2F-FA and stx2R-FA [22] was further analyzed to determine if it indeed harbored stx 2 gene by Southern hybridization using biotin-labeled polynucleotide probe. The stx2 PCR product of SEHC3 reacted with the probe suggesting the presence of stx 2 sequence (Figure-3). This is presumably a variant $s t x 2$ gene and its characterization by cloning and sequencing is currently in progress. Although more than 20 sequence variants of $s t \times 2$ have been reported, these are placed under 7 major subtypes designated as stx2a, stx $2 b, s t \times 2 c$, $s t x 2 d$, stx2e, stx2f, and stx2g [8]. There are not many reports on the occurrence of STEC with variant stx genes in seafood from India.

Although the primer combinations BGRID [25] and stx1F-PA [23] amplified whole stxl genes in 6 isolates, the combination failed to amplify the gene in CEC-1. However, by replacing the reverse primer stx1F-PA with stx1R-FA [22], the stxl gene of CEC-1 could be amplified. This suggests that the isolate CEC-1 could be harboring a variant stxl gene not reported so far. All isolates except CEC-1 were positive by stxlc PCR [26], but their stxl gene sequences were not identical with stx $1 c$. Stx $1 \mathrm{c}$ has $97.1 \%$ and $96.6 \%$ amino acid sequence identity in its A and B subunits, respectively, with the stxl encoded by bacteriophage 933J [26]. Stx $1 \mathrm{~d}$ has a greater sequence variation with only $91 \%$ amino acid identity with the Stx 1 of 933J [27]. The use of different combinations of stx primers and sequencing of full-length stx 1 gene enabled the identification of stxld variants in this study, which otherwise would have been misidentified as stxlc.

The presence of variant stx genes has several implications. First, the genes may be missed by regular PCR using primers designed based on known sequences $[16,27]$. Further, STEC harboring variant genes may represent their reservoirs, such as the stxl variant Stx1OX3 which is of ovine origin [36]. stxlc, for example, has not been reported from EHEC serogroups O26, O103, O111, O145, or O157 and stxlc-harboring E. coli lack eae gene [26]. This also points out at the fact that STEC harboring variant Shiga toxin genes may vary greatly in their virulence gene compositions and hence in their virulence to humans. 
Previous studies from India have shown the presence of stx gene variants in STEC isolated from different sources. A study reported that $s t x 1, \operatorname{stx} 1 c$, stx $2 c$, stx $2 d$ genes were prevalent in STEC isolates of human origin in India [33]. Of 187 fecal samples tested, stxlc was found in $13(30.70 \%)$ isolates, while stx $2 c$ and stx $2 d$ were found in $8(24.24 \%)$ and in $2(6.06 \%)$ isolates, respectively [33]. A study conducted to determine the prevalence and distribution of various variants of stx gene in STEC isolates from the animal stool, meat, and human illness reported the presence of stxld gene [37]. Kumar et al. reported stx lc gene from beef samples of Mangalore, India [16]. These stxlc-positive isolates lacked eaeA and hlyA genes [16]. The present study constitutes the first report on the prevalence of STEC harboring stxld variant genes in seafood from India.

The results of this study proved the occurrence of STEC in fresh seafood and also STEC with variant Shiga toxin genes. The presence of $E$. coli with pathogenic potentials such as the STEC is of great concern. As seen in this study, seafood isolates of STEC are very diverse in contrast to clinical isolates which are more or less homogenous. The presence of diverse genotypes of STEC in seafood may be attributed to diverse sources of contamination of seafood. Since some of the virulence genes such as stx and hlyA are phage or plasmid encoded, dissemination of virulence genes in the aquatic environment may result in the emergence of more virulent strains of pathogens. Further, based on the PCR and sequencing results of this study, it may be hypothesized that more variants of Shiga toxin genes may exist in the environment in the region of this study. Probe hybridization and sequencing will help to identify the variant Shiga toxin genes in seafood associated STEC.

\section{Authors' Contributions}

SK conceived and designed the experiments; SP and PP performed the experiments. SK, BBN, and ML collectively planned and supervised the experiments and analyzed the data. All authors read and approved the final manuscript.

\section{Acknowledgments}

The research was funded by ICAR-CIFE (Grant no. CIFE-2012/9). The authors thank the Director, ICAR-CIFE, Mumbai for help and support. The first author is grateful to Indian Council of Agricultural Research (ICAR) for the junior research fellowship during her master's program.

\section{Competing Interests} interests.

The authors declare that they have no competing

\section{References}

1. Jang, J., Hur, H.G., Sadowsky, M.J., Byappanahalli, M.N., Yan, T. and Ishii, S. (2017) Environmental Escherichia coli:
Ecology and public health implications-a review. J. Appl. Microbiol., 123: 570-581.

2. Riley, L.W. (2014) Pandemic lineages of extra intestinal pathogenic Escherichia coli. Clin. Microbiol. Infect., 20: $380-90$.

3. Gomes, T.A.T., Elias, W.P., Scaletsky, I.C.A., Guth, B.E.C., Rodrigues, J.F., Piazza, R.M.F., Ferreira, L.C. and Martinez, M.B. (2016) Diarrheagenic Escherichia coli. Braz. J. Microbiol., 47: 3-30.

4. Skinner, C., Zhang, G., Patfield, S. and He, X. (2015) An in vitro combined antibiotic-antibody treatment eliminates toxicity from Shiga toxin-producing Escherichia coli. Antimicrob. Agents Chemother., 59: 5435-5444.

5. Krüger, A. and Lucchesi, P.M. (2015) Shiga toxins and stx phages: Highly diverse entities. Microbiology, 161: 451-462.

6. Steiner, T.S. (2016) New insights into Shiga toxigenic Escherichia coli pathogenesis: When less is more. J. Infect. Dis., 213: 1214-1215.

7. Farrokh, C., Jordan, K., Auvray, F., Glass, K., Oppegaard, H., Raynaud, S., Thevenot, D., Condron, R., De Reu, K., Govaris, A., Heggum, K., Heyndrickx, M., Hummerjohann, J., Lindsay, D., Miszczycha, S., Moussiegt, S., Verstraete, K. and Cerf, O. (2013) Review of Shiga-toxin-producing Escherichia coli (STEC) and their significance in dairy production. Int. J. Food Microbiol., 162: 190-212.

8. Baranzoni, G.M., Fratamico, P.M., Gangiredla, J., Patel, I., Bagi, L.K., Delannoy, S., Fach, P., Boccia, F., Anastasio, A. and Pepe, T. (2016) Characterization of Shiga toxin subtypes and virulence genes in porcine Shiga toxin-producing Escherichia coli. Front. Microbiol., 7: 574.

9. Jajarmi, M., Imani Fooladi, A.A., Badouei, M.A. and Ahmadi, A. (2017) Virulence genes, Shiga toxin subtypes, major O-serogroups, and phylogenetic background of Shiga toxin-producing Escherichia coli strains isolated from cattle in Iran. Microb. Pathog., 109: 274-279.

10. Kobayashi, N., Lee, K., Yamazaki, A., Saito, S., Furukawa, I., Kono, T., Maeda, E., Isobe, J., Sugita-Konishi, Y. and HaraKudo, Y. (2013) Virulence gene profiles and population genetic analysis for exploration of pathogenic serogroups of Shiga toxin-producing Escherichia coli. J. Clin. Microbiol., 51: 4022-4028

11. Smith, J.L., Fratamico, P.M., Gunther, N.W.4 ${ }^{\text {th }}$ (2014) Shiga toxin-producing Escherichia coli. Adv. Appl. Microbiol., 86: 145-197.

12. Gould, L.H., Mody, R.K., Ong, K.L., Clogher, P., Cronquist, A.B., Garman, K.N., Lathrop, S., Medus, C., Spina, N.L., Webb, T.H., White, P.L., Wymore, K., Gierke, R.E., Mahon, B.E. and Griffin, P.M. (2013) Increased recognition of non-O157 Shiga toxin-producing Escherichia coli infections in the United States during 20002010: epidemiologic features and comparison with E. coli O157 infections. Foodborne Pathog. Dis., 10: 453-460.

13. Luna-Gierke, R.E., Griffin, P.M., Gould, L.H., Herman, K., Bopp, C.A., Strockbine, N. and Mody, R.K. (2014) Outbreaks of non-O157 Shiga toxin-producing Escherichia coli infection: USA. Epidemiol. Infect., 142: 2270-2280.

14. Perelle, S., Dilasser, F., Grout, J. and Fach, P. (2007) Screening food raw materials for the presence of the world's most frequent clinical cases of Shiga toxin-encoding Escherichia coli O26, O103, O111, O145 and O157. Int. J. Food Microbiol., 113: 284-288.

15. Beutin, L., Geier, D., Steinrück, H., Zimmermann, S. and Scheutz, F. (1993) Prevalence and some properties of verotoxin (Shiga-like toxin)-producing Escherichia coli in seven different species of healthy domestic animals. J. Clin. Microbiol., 31: 2483-2488.

16. Kumar, H.S., Karunasagar, I., Karunasagar, I., Teizou, T., Shima, K. and Yamasaki, S. (2004) Characterisation of Shiga toxin-producing Escherichia coli (STEC) isolated from seafood and beef. FEMS Microbiol. Lett., 233: 173-178. 
17. Samadpour, M., Ongerth, J.E., Liston, J., Tran, N., Nguyen, D., Whittam, T.S., Wilson, R.A. and Tarr, P.I. (1994) Occurrence of Shiga-like toxin-producing Escherichia coli in retail fresh seafood, beef, lamb, pork, and poultry from grocery stores in Seattle, Washington. Appl. Environ. Microbiol., 60: 1038-1040.

18. Kumar, H.S., Otta, S.K., Karunasagar, I. and Karunasagar, I. (2001) Detection of Shiga-toxigenic Escherichia coli (STEC) in fresh seafood and meat marketed in Mangalore, India by PCR. Lett. Appl. Microbiol., 33: 334-338.

19. FDA. (2004) Bacteriological Analytical Manual. US Food and Drug Administration Center for Food Safety, Washington, DC.

20. Ausubel, F.M., Brent, R., Kingsten, R.E., Moore, D.D., Seidman, J.G., Smith, J.A. and Struhl, K. (1995). Short Protocols in Molecular Biology. $3^{\text {rd }}$ ed. Wiley, New York.

21. Yamasaki, S., Lin, Z., Shirai, H., Terai, A., Oku, Y., Ito H., Ohmura, M., Karasawa, T., Tsukamoto, T., Kurazono, H. and Takeda, Y. (1996) Typing of verotoxins by DNA colony hybridization with poly-and oligonucleotide probes, a bead-enzyme-linked immunosorbent assay, and polymerase chain reaction. Microbiol. Immunol., 40: 345-352.

22. Fagan, P.K., Hornitzky, M.A., Bettelheim, K.A. and Djordjevic, S.P. (1999) Detection of shiga-like toxin (stxl and stx2), intimin (eaeA), and enterohemorrhagic Escherichia coli (EHEC) hemolysin (EHEC hlyA) genes in animal feces by multiplex PCR. Appl. Environ. Microbiol., 65: 868-872.

23. Paton, A.W. and Paton, J.C. (1998) Detection and characterization of Shiga toxigenic Escherichia coli by using multiplex PCR assays for $s t x 1, s t x 2$, eaeA, enterohemorrhagic E. coli hlyA, rfbO111, and rfbO157. J. Clin. Microbiol., 36: 598-602

24. Karch, H. and Meyer, T. (1989) Single primer pair for amplifying segments of distinct Shiga-like-toxin genes by polymerase chain reaction. J. Clin. Microbiol. 27: 2751-2757.

25. Lee, J.E., Reed, J., Shields, M.S., Spiegel, K.M., Farrell, L.D. and Sheridan, P.P. (2007) Phylogenetic analysis of Shiga toxin 1 and Shiga toxin 2 genes associated with disease outbreaks. BMC Microbiol., 7: 109.

26. Zhang, W., Bielaszewska, M., Kuczius, T. and Karch, H. (2002) Identification, characterization, and distribution of a Shiga toxin 1 gene variant $(\mathrm{stx}(1 \mathrm{c}))$ in Escherichia coli strains isolated from humans. J. Clin. Microbiol., 40: 1441-1446.

27. Bürk, C., Dietrich, R., Açar, G., Moravek, M., Bülte, M. and
Märtlbauer, E. (2003) Identification and characterization of a new variant of Shiga toxin 1 in Escherichia coli ONT: H19 of bovine origin. J. Clin. Microbiol., 41: 2106-2112.

28. Brown, T. (2001) Current Protocols in Molecular Biology. John Wiley \& Sons, New York.

29. Kessler, C. (1992) Nonradioactive Labeling and Detection of Biomolecules. Springer-Verlag, New York.

30. Bitton, G. (1994) Wastewater Microbiology. Wiley-Liss, New York.

31. Pal, A., Ghosh, S., Ramamurthy, T., Yamasaki, S., Tsukamoto, T., Bhattacharya, S.K., Nair, G.B. and Takeda, Y. (1999) Shiga-toxin producing Escherichia coli from healthy cattle in a semi-urban community in Calcutta, India. Indian J. Med. Res., 110: 83-85.

32. Kumar, A., Taneja, N., Sharma, R.K., Sharma, H., Ramamurthy, T. and Sharma, M. (2014) Molecular characterization of Shiga-toxigenic Escherichia coli isolated from diverse sources from India by multi-locus variable number tandem repeat analysis (MLVA). Epidemiol. Infect., 142: 2572-2582.

33. Wani, S.A., Hussain, I., Nabi, A., Fayaz, I. and Nishikawa, Y. (2007) Variants of eae and stx genes of atypical enteropathogenic Escherichia coli and non-O157 Shiga toxin-producing Escherichia coli from calves. Lett. Appl. Microbiol., 45(6): 610-5.

34. Khan, A., Yamasaki, S., Sato, T., Ramamurthy, T., Pal, A., Datta, S., Chowdhury, N.R., Das, S.C., Sikdar, A., Tsukamoto, T., Bhattacharya, S.K., Takeda, Y. and Nair, G.B. (2002) Prevalence and genetic profiling of virulence determinants of non-O157 Shiga toxin-producing Escherichia coli isolated from cattle, beef, and humans, Calcutta, India. Emerg. Infect. Dis., 8: 54-62.

35. Surendraraj, A., Thampuran, N. and Joseph, T.C. (2010) Molecular screening, isolation, and characterization of enterohemorrhagic Escherichia coli O157:H7 from retail shrimp. J. Food Prot., 73: 97-103.

36. Koch, C., Hertwig, S., Lurz, R., Appel, B. and Beutin L. (2001) Isolation of a lysogenic bacteriophage carrying the stx $(1(\mathrm{OX} 3))$ gene, which is closely associated with Shiga toxin-producing Escherichia coli strains from sheep and humans. J. Clin. Microbiol., 39: 3992-3998.

37. Kumar, A., Taneja, N., Kumar, Y. and Sharma, M. (2012) Detection of Shiga toxin variants among Shiga toxin-forming Escherichia coli isolates from animal stool, meat and human stool samples in India. J. Appl. Microbiol., 113: 1208-1216.

\section{$* * * * * * * *$}

